\section{Pacific Northwest} National Laboratory

Operated by Battelle for the

U.S. Department of Energy

\title{
Discussion Forum for Technical Codes Users
}

B. Kaspar

H.E. Dillon

March 2006

Prepared for the U.S. Department of Energy under Contract DE-AC05-76RL01830

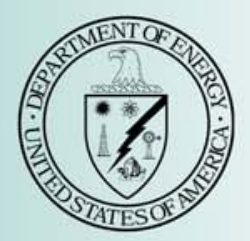




\title{
DISCLAIMER
}

This report was prepared as an account of work sponsored by an agency of the United States Government. Neither the United States Government nor any agency thereof, nor Battelle Memorial Institute, nor any of their employees, makes any warranty, express or implied, or assumes any legal liability or responsibility for the accuracy, completeness, or usefulness of any information, apparatus, product, or process disclosed, or represents that its use would not infringe privately owned rights. Reference herein to any specific commercial product, process, or service by trade name, trademark, manufacturer, or otherwise does not necessarily constitute or imply its endorsement, recommendation, or favoring by the United States Government or any agency thereof, or Battelle Memorial Institute. The views and opinions of authors expressed herein do not necessarily state or reflect those of the United States Government or any agency thereof.

\author{
PACIFIC NORTHWEST NATIONAL LABORATORY \\ operated by \\ BATTELLE \\ for the \\ UNITED STATES DEPARTMENT OF ENERGY \\ under Contract DE-AC05-76RL01830
}

Printed in the United States of America

Available to DOE and DOE contractors from the

Office of Scientific and Technical Information,

P.O. Box 62, Oak Ridge, TN 37831-0062;

ph: (865) 576-8401

fax: $(865) 576-5728$

email: reports@adonis.osti.gov

\author{
Available to the public from the National Technical Information Service, \\ U.S. Department of Commerce, 5285 Port Royal Rd., Springfield, VA 22161 \\ ph: (800) 553-6847 \\ fax: (703) 605-6900 \\ email: orders@ntis.fedworld.gov \\ online ordering: http://www.ntis.gov/ordering.htm
}

This document was printed on recycled paper.

$(9 / 2003)$ 
PNNL-15757

\section{Discussion Forum for Technical Codes Users}

B. Kaspar

H.E. Dillon

March 2006

Prepared for

the U.S. Department of Energy

under Contract DE-AC05-76RL01830

Pacific Northwest National Laboratory

Richland, Washington 99352 


\subsection{Introduction}

The Building Energy Codes Program (BECP) provides useful, easy-to-understand information about national energy codes as well as user support for its many software tools. In the last two fiscal years, the number of support requests to BECP staff has almost doubled. Growing demand will overtax the existing support system, which relies on one-on-one interaction provided by an electronic mail-based system, textbased help files within BECP's software applications, and web-based presentations and videos. In addition to the problem of growing demand, the comparatively non-interactive nature of the existing system could be an impediment to learning for some users ${ }^{[1]}$. The BECP would benefit from an alternative support option that would enable their current support resources to address members of a wide audience simultaneously as well as help new users explore software capabilities. An effective support option that meets these requirements and is already employed by other government agencies is a discussion forum. The BECP staff recommends an Energycodes discussion forum be implemented to benefit users.

\subsection{Lessons Learned}

Numerous studies have shown the value of "asynchronous online discussions" ${ }^{[1]}$. While this research is focused on the application of these techniques to higher education, there is commonality in the BECP's educational goals. Online discussions were found to be most useful for conceptual learning among groups of people who could not meet in person and in an environment where the instructors were present in the discussions. Discussion forums were also found to generate feelings of community among participants and to facilitate collaborative learning ${ }^{[2]}$. Also note that the permanent storage and threading of messages has been shown to improve the utility of the discussion forum ${ }^{[1]}$.

There is less research available on discussion forums for technical support, but it has been found that participants in these communities help each other to use software products. They reinforce the value of the product in their lives through shared experiences and assist other users in any difficulties they may have ${ }^{[3]}$. They also benefit from a learning effect that improves their professional skills ${ }^{[4]}$.

The design of the Energycodes discussion forum would be optimized by applying lessons learned from discussion forum research. Its purpose would be twofold: (1) to educate the community on the implications and practices of new and existing building energy codes and (2) to provide support for the existing software tools. The Energycodes discussion forum would be a staff-moderated discussion board where staff would post topics and users would discuss those topics with staff and other users. The forum would be moderated by staff members, to remove objectionable and irrelevant postings and to answer any technical questions that arise. The topics and discussions would be archived and searchable to allow users to answer their own questions pertaining to a previously discussed topic.

\subsection{Advantages of Discussion Forums and Benefit to the BECP and Users}

- Generate a two way flow of information. As topics are discussed and critiqued by end users, BECP staff would assess how much resistance there is to a specific set of energy code changes and/or concepts as well as locate areas of wide-spread confusion. This allows staff to tailor the education and outreach programs to the user community. 
- Increase the speed at which user's questions are answered. With the Energycodes discussion forum, users would no longer be reliant on the limited technical support staff of the BECP, but instead could rely on other users with a better grasp of the codes framework and software.

- Provide additional support to the Washington State Energy Office and the EERE support group. The Energycodes discussion forum would generate a large group of searchable questions and answers to common problems.

\subsection{Disadvantages of Discussion Forums and BECP Solutions}

- Anonymity can provide an opportunity for objectionable content. If there is no way to control the material posted by users, and users are completely anonymous, then illicit and illegal content can end up as forum postings. Anonymous users will not be allowed to post content to the discussion forum.

- Active moderation by staff will be required. Staff would remove unauthorized postings as they are identified. This would also satisfy the legal requirements for restricted and copywritten content. Moderation would require an ongoing time and financial commitment.

- Possible liability for incorrect information in postings. Inaccurate postings could reflect negatively on the BECP and DOE brand. Similar strategies as those outlined for active moderation of the discussion forum would be implemented to reduce this possibility. This concept has been explored with the PNNL server and security team. Additional legal review would be provided by PNNL before the system was implemented. A legally approved disclaimer on the forum to remove the Energy Codes program from any liability would be developed.

\subsection{Examples of Discussion Forums in Government}

A number of government agencies successfully use discussion forums at present to provide user support for software tools and to facilitate communication among technical project team members. Some examples of these forums are highlighted below.

- DOE's EnergyPlus software has maintained a hybrid forum for user support for several years. The system functions as a global mailing list rather than a web forum, but the same disadvantages and legal issues exist. This forum is moderated by staff from the EnergyPlus team and is used by DOE staff, laboratory staff, and external contractors. http://groups.yahoo.com/group/EnergyPlus_Support/

- The Environmental Protection Agency has an established moderated forum for Air Quality Systems that provides technical information to users. http://yosemite1.epa.gov/oar/Forums.nsf/Forum/AIRSByTopic?OpenView\&CollapseView

- Sandia National Laboratory has forum support for many software tools, although it is not clear what the funding source is. The Acro software mailing list forum is shown below. http://software.sandia.gov/mailman/listinfo/acro-users

- NASA supports many government-developed software tools, and the World Wind software has an active forum. This forum is widely used (indicates 30,000+ total posts), but is not directly hosted by NASA, rather it is hosted by the software community. http://forum.worldwindcentral.com 
- Brookhaven National Lab hosts forums for multiple projects. The Software and Computing group has more than 50 different online forums related to their technical projects and applications, as well as for general discussion. http://rhicii-science.bnl.gov/HyperNews-star/index

\subsection{Recommendations}

The existing BECP user support system, which relies on one-on-one interaction via email, will not support the projected increase in user demand, and expanding the existing system may not be cost effective. The BECP staff recommends instituting an Energycodes discussion forum. Current technology makes a discussion forum cost effective to build and moderate. A number of free Open Source tools for discussion forums are available, and these tools allow extensive customization. Also, the Energycodes discussion forum would leverage existing BECP software and server resources.

The Energycodes discussion forum should be launched in a two-phase pilot program to enable BECP (1) to better determine the exact maintenance and staffing requirements and (2) to gauge the community interest before a larger investment is made.

The first phase of the pilot would be an internal demo. A population of test users from PNNL staff would use the chosen forum software and evaluate the software for security and usability. Any needed changes to the forum would be made at this time and unforeseen issues would be identified. There would be a minimal cost for this phase of the pilot, as existing infrastructure will be used and the small user base will limit the staff hours required.

The second phase of the pilot would be a limited public pilot installation. Phase two would be to a select group of external users with careful monitoring of the software and content. It would also use existing infrastructure but would require a larger staff time commitment to moderate and resolve issues. This limited public pilot would be an excellent gauge of the approximate volume of forum usage as well as of the ongoing staff time needed for moderation and maintenance.

\subsection{References}

1. Hammond M. 2005. A Review of Recent Papers on Online Discussion in Teaching and Learning in Higher Education. Journal of Asynchronous Learning Networks 9(3).

2. Brown R. 2001. The Process of Community-Building in Distance Learning Classes. Journal of Asynchronous Learning Networks 5(2):18-35.

3. Pór G. 2004. Liberating the Innovation Value of Communities of Practice. Accessed at http://www.efios.com/pdf/innovation_value.pdf.

4. Curien N, G Laffond, J Lainé, and F Moreau. Who Should Contribute to Online Communities? Accessed at http://e.darmon.free.fr/workcommed/papers/curien_laffond_laine_moreau_4_nice.pdf. 